Article

\title{
Environmental burdens of External Thermal Insulation Systems. Expanded Polystyrene vs. Mineral Wool: Case Study from Poland
}

\author{
Jacek Michalak@, Sebastian Czernik, Marta Marcinek and Bartosz Michałowski * \\ Research and Development Center, Atlas sp. z o.o., 2, Kilinskiego St., 91-421 Lodz, Poland; \\ jmichalak@atlas.com.pl (J.M.); sczernik@atlas.com.pl (S.C.); mmarcinek@atlas.com.pl (M.M.) \\ * Correspondence: bmichalowski@atlas.com.pl
}

Received: 13 May 2020; Accepted: 28 May 2020; Published: 2 June 2020

\begin{abstract}
The external thermal insulation composite system (ETICS) improves the energy efficiency of buildings, and nowadays, this method is the most popular to insulate buildings in many European Union (EU) countries. The article presents the impact of producing ETICS with expanded polystyrene (EPS) or mineral wool (MW) on the natural environment using the life cycle assessment (LCA) method. The data used in the calculations, related to 2017 real production, were obtained from the externally verified inventory from five manufacturing plants located in different regions of Poland. The LCA of the examined products covered modules from A1 to A3 (cradle-to-gate), according to EN 15804 standard. The study determines and analyses the values of basic indicators related to environmental impacts and environmental aspects of resource use. It comprises indicators calculated for $1 \mathrm{~m}^{2}$ ETICS for five thicknesses of the mentioned thermal insulation materials. Results show that for all environmental indicators, MW systems are characterized by a more negative environmental impact than the equivalent systems with EPS. The study aims to highlight knowledge about ETICS sustainability. The data presented in work are essential for assessment in terms of the sustainable development of ETICS. Such an evaluation is not just a need for the future but a necessity for the present.
\end{abstract}

Keywords: environmental impact; environmental product declaration (EPD); life cycle assessment (LCA); external thermal insulation composite system (ETICS); global warming potential (GWP)

\section{Introduction}

Protection, preservation, and improvement of natural capital, as well as the protection of citizens' health and well-being against threats and adverse effects related to environmental degradation, is one of the most critical challenges of today. Recently, the European Commission, recognizing the need to intensify efforts to counteract the negative impact of man on the environment expertly, has formulated a new strategy: the European Green Deal [1]. The goal is to achieve zero net greenhouse gas emissions in the European Union (EU) in 2050. The implementation of this goal involves the separation of economic growth from the use of natural resources.

The construction, use, and renovation of buildings require considerable energy and mineral resources. [The building sector in the EU is the largest single energy consumer, accounting for $40 \%$ of the total energy used [2]. As a result of the energy demand for construction, $36 \%$ of total carbon dioxide $\left(\mathrm{CO}_{2}\right)$ emissions are generated in the European Union. In the EU, 75\% of buildings are energy inefficient [3]. In the Member States, the annual building renovation rate is between $0.4 \%$ and $1.2 \%$ today [1]. There is no chance of achieving the target set in the European Green Deal in 2050 without doubling this indicator. Thus, it is necessary to start renovating buildings, both public and private, 
on a more massive scale. The most commonly used method to save energy in buildings in EU countries is through the use of external thermal insulation composite systems (ETICS).

The construction sector, corresponding to $9 \%$ of European GDP and 18 million direct jobs, is responsible for the most significant damage to the environment among all branches of the economy. The scale of its negative impact has also been confirmed at the global level. In 2015, fossil fuels were the source of $82 \%$ of the energy consumed in buildings in EU countries [4]. Still, the current approach of participants in the construction process (architect, constructor, contractor, and investor) for environmental impact is based on the strategy of meeting immediate needs. In most cases, the main goal is to erect the object, preferably with the lowest possible investment. Design and construction of buildings without assessing its long-term impact (by means of its full life cycle) on the natural environment is still permitted by law. Shortly it will be necessary to change this approach.

Construction Products Regulation (CPR) has been marketing the construction products in the EU countries since 1 July 2013 [5]. The authors of the CPR have introduced the issue of product sustainability in the regulation of construction products. Before 1 July 2013, Directive 89/106/EEC [6] defined six basic requirements related to:

1. mechanical resistance and stability,

2. safety in case of fire,

3. hygiene, health, and environment,

4. safety in use,

5. protection against noise,

6. energy economy and heat retention.

According to the CPR, construction works must be designed, built and demolished in such a way as to ensure the sustainable use of natural resources, and in particular to provide:

- reuse of recyclability of the construction works, their materials, and parts after demolition,

- the durability of the construction works,

- use of environmentally compatible raw and secondary materials in the construction works.

Despite the great importance of the issue of sustainable development $[7,8]$ and the definition of the seventh basic requirement in the CPR, it is not yet a criterion for compulsory assessment before placing a construction product on the EU market. To determine the environmental impact of a construction product, its manufacturer can develop an Environmental Product Declaration (EPD). EPD is an independently checked and registered document that provides transparent and comparable information on the environmental impact of products during their life cycle $[9,10]$. EPD is an internationally recognized and accepted document defining product quality. EPD, also known as a Type III environmental declaration, is based on the life cycle assessment (LCA) and complies with the ISO 14025 standard [11]. EPDs are used in construction, mainly for performing the life cycle assessment of a building (according to EN 15978 [12] or a construction product (according to EN 15804 [13]. Because EPDs are not required by law, and they are only a voluntary document, they are not widely used. It is true that their number increases every year and currently amounts to over 6000 [14]. In Poland, the Building Research Institute (ITB) has issued over 100 EPDs [15]. However, these documents are still used only in business-to-business (B2B) communication and certification processes of such systems like LEED, BREEAM, DGNB, $\mathrm{HQE}^{\circledR}$, and others [16-18]. An ordinary user of construction products knows little or nothing about EPD.

As mentioned above, the application of ETICS improves the energy efficiency of both new and existing buildings. ETICS are kit in the sense of the CPR consisting of specified prefabricated components being applied directly to the facade onsite. The Polish ETICS market, estimated at around 40 million $\mathrm{m}^{2}$ annually, is one of the highest in Europe [19]. Every year, ETICS manufacturers improve the functionality of their solutions by trying to match them to the expectations of customers. Expectations are high, especially considering that a dozen or so years ago, Polish buildings had the 
highest average heating energy consumption: $63 \%$ above the European average [20]. Buildings in Poland, alongside French ones, also had the highest production of airborne emissions and the highest emissions of solid wastes [20]. In Poland, as in other EU countries, with expanded polystyrene (EPS) or mineral wool (MW) panels are commonly used as insulation material in ETICS. It is worthy of mentioning that both materials are in use for decades. In Central Europe, the share of ETICS with EPS is about $84 \%$, while about $12 \%$ of ETICS installed on the walls as thermal insulation material is MW. In other regions of Europe, the share of EPS ranges from $60 \%$ to $88 \%$, and MW from $9 \%$ to $25 \%$ [19]. Systems with EPS and MW can be used both on newly erected buildings and those undergoing modernization. However, there are significant differences between EPS and MW, which can decide on the selection of specific insulation material, and thus the entire insulation system. Below we present the most critical features of both materials, which, due to their practical application, are essential for an investor planning building insulation:

- Thermal insulation characterized by a thermal conductivity coefficient $\lambda$ (or $k, \mathrm{~W} \mathrm{~m}^{-1} \mathrm{~K}^{-1}$ ).

The thermal conductivity coefficient for facade EPS presumably can be found in the range between 0.029 and $0.041 \mathrm{~W} \mathrm{~m}^{-1} \mathrm{~K}^{-1}$ [21], where minimal value is designated for graphite polystyrene. As for mineral wool, the $\lambda$ value commonly is in the range of 0.037 to $0.050 \mathrm{~W} \mathrm{~m}^{-1} \mathrm{~K}^{-1}$ [22].

- Insulation material weight.

Depending on the type, the facade mineral wool is from five to nine times heavier than EPS. Additionally, the consumption of adhesives used for fixing it and embedding fiberglass mesh is about $15 \%$ higher. Approximately, $1 \mathrm{~m}^{2}$ ETICS with $10 \mathrm{~cm}$ thick EPS insulation weighs about $15 \mathrm{~kg}$, where lamella MW panels of the same thickness reach about $22 \mathrm{~kg}$, and on MW with a laminar fiber disturbance up to about $27 \mathrm{~kg}$ [23].

- Water vapor permeability.

This is one of the most important properties when analyzing vapors flows in the wall. Measured water diffusion resistance factor $(\mu)$ is on average equal to 2 and 35 for MW and EPS, respectively. Water vapor permeability is significantly lower for EPS because of its structure and the high share of tightly closed pores [23]. On the other hand, the disadvantages of high permeability of MW are possibly easier condensation between materials fibers which can affect negatively the properties of thermal conductivity [24].

- $\quad$ Fire resistance.

According to the classification of thermal insulation materials through EN 13501-1 [25], MW (European fire classes: Euroclasses A1 and A2) is in a solid privileged position compared to EPS (European fire classes: Euroclasses F and E). Nevertheless, according to the same norm, classifications of ETICS with MW and EPS (with external mineral layer) are as follows, A2-s2-d0 and B-s1-d0, respectively. Described ETICS classification concerns systems described further in the Materials and Methods section and is representative for ETICS based on MW and EPS as thermal insulation material and mineral rendering system. It is worth to mention that properly designed and built ETICS based on both MW or EPS are classified as non-spreading fire according to Polish norm PN-B-02867:2013 [26].

From a practical aspect, when comparing systems based on different insulation materials, it is also essential to consider the mounting method, and the total cost of investment in insulation MW-ETICS to EPS-ETICS (identical insulation thickness and the same finishing layers) can be significantly higher. As mentioned earlier, the environmental impact of ETICS is not considered during the assessment of the system and laying down product on the market. It is also not commonly determined when making an ETICS selection by an investor, architect, or the final consumer. The exception is when the building 
is assessed in one of the voluntary environmental assessment systems. Despite the importance of environmental issues and the widespread use of ETICS, as well as extensive scientific literature in the field of LCA and EPD, the number of scientific publications on ETICS environmental impacts is still limited [27-32]. This work compares EPS based ETICS to MW based ETICS environmental impact.

\section{Materials and Methods}

ETICS consists of a prefabricated insulation product bonded to the wall or mechanically fixed with anchors, or a combination of adhesive and mechanical fixings. This technique was applied for the first time to a residential building in 1957 in Berlin, Germany [19]. Over the past 60 years, ETICS has been and continues to be the most widely used solution to improve the energy efficiency of buildings in Europe. Thus, this solution has flowed over the years and continues to affect the achievement of environmental goals [19].

In Poland, construction products can be laid down on the market with the CE marking or in the system on the national level with the construction mark B. At the European level, the requirements for ETICS are set out in ETAG 004 [33]. In Poland, ETICS manufacturers can obtain a European Technical Assessment based on ETAG 004 and, after subjecting their solution to conformity assessment, place on the market with CE marking. It is also possible to obtain the National Technical Assessment (before 1 January 2017, National Technical Approval), and after completing the conformity assessment, mark the product with the building mark B. In the national system, the requirements for granting the National Technical Assessment for ETICS with EPS and MW are specified in the relevant guideline for issuing national technical assessments (for EPS based ETICS [34] and MW based ETICS [35]).

In the Polish national assessment system, ETICS is subject to assessment in the same basic requirements using the same test methods as in the European order. Besides, due to regulations on the national level, it is possible to assess the fire spread rate and susceptibility to algae growth.

Atlas ETICS and Atlas ETICS Roker are trading names for External Thermal Insulation Composite System. Both systems comprise the insulation board (bonded or bonded and mechanically fixed) with reinforced undercoat and decorative finishes, as described in the National Technical Approval ITB AT-15-9090/2016 (EPS) [36] and ITB AT-15-2930/2016 (MW) [37] issued by the Building Research Institute (ITB) in Warsaw. The systems consist of a vast selection of adhesives, base coats, renders, and decorative coats of various colors. Figure 1 schematically shows the arrangement of ETICS layers.

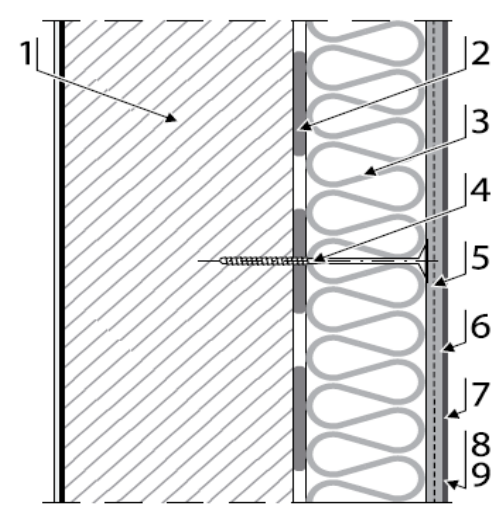

Figure 1. Layers arrangement in the Atlas external thermal insulation composite system (ETICS) (expanded polystyrene (EPS)) and Atlas ETICS Roker (mineral wool (MW)) as described in the National Technical Approval AT-15-9090/2016 and AT-15-2930/2016: (1) wall structure (substrate), (2) adhesive (basic fixing), (3) thermal insulation (EPS or MW), (4) anchor (if necessary, additional fixing), (5) reinforcement layer (base coat with glass fiber mesh embedded), (6) key coating (if needed), (7) finishing coat (renders), (8) primers (optional), and (9) decorative coats (optional). 
For the study presented in this paper, mineral renders systems selected from various possible variants described in the ITB AT-15-9090/2016 (EPS), and ITB AT-15-2930 (MW) were analyzed [36,37].

The environmental impact was assessed using the LCA method for a complex thermal insulation system described in the National Technical Approval AT-15-9090/2016 (EPS) and AT-15-2930/2016 (MW). For this publication, the results obtained for ETICS containing expanded polystyrene (EPS) or mineral wool (MW) panels of five different thicknesses: 10, 12, 15, 20, and $25 \mathrm{~cm}$ with a mineral render as a finish layer were analyzed.

The data used in the calculations relate to 2017 (EPD's released in March 2019) for five production plants located in the different regions of Poland: Bydgoszcz, Dabrowa Górnicza, Piotrków Trybunalski, Suwałki, and Zgierz [38,39]. It is also worth noting that during 2017, the production volume of ETICS components corresponded to approximately 10 million square meters of insulation of the external walls of buildings. Type III Environmental Declarations (EPD) was developed by following EN 15804 [13], and their content was verified per under ISO 14025 [11] by Building Research Institute (ITB) experts. The life cycle that was the subject of the analysis covered modules A1 to A3 (i.e., from the extraction of raw material to the finished product delivered to the factory gate), where A1 is extraction, and processing of raw materials, processing of secondary material, including recycling processes, A2 is transport to the manufacturer, and A3 is production. The total values of modules A1, A2, and A3 for studied ETICS have been analyzed in this paper. For a better understanding, it is worth mentioning that the share of module A1 in the total A1 + A2 + A3 in the case of ETICS with EPS ranged from $94.14 \%$ (for EPS thickness of $10 \mathrm{~cm}$ ) up to $96.82 \%$ ( $25 \mathrm{~cm}$ thick). For ETICS with MW, the A1 module was from $98.11 \%$ ( $10 \mathrm{~cm}$ of EPS) to $99.14 \%$ ( $25 \mathrm{~cm}$ EPS). The transport share for ETICS with EPS (module A2) ranged from $1.44 \%$ to $0.80 \%$ for 10 and $25 \mathrm{~cm}$ EPS thick, respectively. For ETICS with MW, the share of the A2 module varied from $0.38 \%$ to $0.17 \%$ for EPS 10 and $25 \mathrm{~cm}$ thick. The share of module A3 (production) ranged from $4.42 \%$ to $2.38 \%$ for ETICS with EPS for 10 and $25 \mathrm{~cm}$ thick, respectively. For ETICS with MW, the share of module A3 was lower than for ETICS with EPS. It was only $1.38 \%$ for a $10 \mathrm{~cm}$ MW thickness and $0.69 \%$ for a $25 \mathrm{~cm}$ MW thickness.

The environmental assessment refers to the product unit, which is $1 \mathrm{~m}^{2}$ of insulation made using a complex insulation system described in the National Technical Approvals AT-15-9090/2016 (EPS) and AT-15-2930/2016 (MW). The impacts and consumption of raw materials for each production plant and the entire production were assigned to representative products through the application of mass allocation rules (i.e., the weighted average mass of given products). Impacts at individual production locations have been inventoried, assigned, and included in the calculations separately.

Table 1 specifies all components of the ETICS with expanded polystyrene (EPS) described in the National Technical Approval ITB-AT-15-9090/2016 and analogous data for the ETICS with mineral wool (MW), as described in ITB-AT-15-2930/2016. 
Table 1. EITCS components as described in the National Technical Approval ITB AT-15 9090/2016 (for ETICS with EPS) and ITB AT-15-2930/2016 (for ETICS with MW).

\begin{tabular}{|c|c|c|c|}
\hline Component & Component Description & $\begin{array}{c}\text { Quantity/m² } \\
\text { ETICS with EPS }\end{array}$ & $\begin{array}{c}\text { Quantity/m² } \\
\text { ETICS with MW }\end{array}$ \\
\hline Adhesive for bonding & $\begin{array}{l}\text { Cement-based adhesives modified } \\
\text { with re-dispersible polymer } \\
\text { powder, methylcellulose ether, } \\
\text { fibers, and mineral fillers. }\end{array}$ & $4.5 \mathrm{~kg}$ & $4.5-5.5 \mathrm{~kg}$ \\
\hline Insulation ${ }^{1}$ & $\begin{array}{l}\text { Prefabricated EPS board or } \\
\text { MWpanel. }{ }^{2}\end{array}$ & ca. $1.35 \mathrm{~kg}$ & $3.5-4.5 \mathrm{~kg}$ \\
\hline Adhesive for base coat & $\begin{array}{l}\text { Cement-based adhesives modified } \\
\text { with re-dispersible polymer } \\
\text { powder, methylcellulose ether, } \\
\text { fibers, and mineral fillers. }\end{array}$ & $5.5 \mathrm{~kg}$ & $5.5-6.5 \mathrm{~kg}$ \\
\hline Glass fiber mesh ${ }^{1}$ & $\begin{array}{l}\text { Alkaline-resistant glass mesh with } \\
\text { a nominal weight of } 150 \text { or } 165 \\
\mathrm{~g} / \mathrm{cm}^{2} .\end{array}$ & $\geq 0.15 \mathrm{~kg}$ & $\geq 0.15 \mathrm{~kg}$ \\
\hline Key coat & $\begin{array}{l}\text { Dispersion-based key coat with } \\
\text { mineral/quartz fillers. }\end{array}$ & ca. $0.2 \mathrm{~kg}$ & ca. $0.3 \mathrm{~kg}$ \\
\hline Finishing coat & $\begin{array}{l}\text { Cement-based render modified } \\
\text { with re-dispersible polymer } \\
\text { powder, methylcellulose ether, } \\
\text { fibers, and mineral fillers. }\end{array}$ & $2.0-4.5 \mathrm{~kg}$ & $2.0-4.5 \mathrm{~kg}$ \\
\hline Ancillary materials ${ }^{1}$ & Anchors, special fittings. & - & - \\
\hline
\end{tabular}

The environmental data on raw materials used in the analysis come from valid sources (databases) such as Ecoinvent, Ullmann's, Plastic-Europe, ITB-Data, SPC, and selected Type III environmental declarations of components of ETICS.

\section{Results}

Table 2 shows the environmental characteristics of ETICS with different thicknesses of EPS insulation material and mineral renders as the finishing layer calculated for $1 \mathrm{~m}^{2}$ of insulation, of:

- global warming potential (GWP),

- depletion potential of the stratospheric ozone layer (ODP),

- $\quad$ acidification potential of soil and water (AP),

- eutrophication potential (EP),

- formation potential of tropospheric ozone (POCP),

- abiotic depletion potential (ADP-elements) for non-fossil resources,

- abiotic depletion potential (ADP-fossil fuels) for fossil resources,

- $\quad$ total use of renewable primary energy resources (primary energy and primary energy resources used as raw materials) (PERT),

- $\quad$ total use of non-renewable primary energy resources (primary energy and primary energy resources used as raw materials) (PENRT) 
Table 2. Environmental characteristics of $1 \mathrm{~m}^{2}$ ETICS system described in the National Technical Approval AT-15-9090/2016 calculated in the year 2019 (data from 2017) with 10, 12, 15, 20, and $25 \mathrm{~cm}$ of expanded polystyrene (EPS) used as thermal insulation material, and mineral renders as a finishing layer [38].

\begin{tabular}{|c|c|c|c|c|c|}
\hline \multirow{2}{*}{ Indicator [Unit] } & \multicolumn{5}{|c|}{ A1-A3 } \\
\hline & $10 \mathrm{~cm}$ & $12 \mathrm{~cm}$ & $15 \mathrm{~cm}$ & $20 \mathrm{~cm}$ & $25 \mathrm{~cm}$ \\
\hline \multicolumn{6}{|c|}{ Environmental Impacts: $1 \mathrm{~m}^{2}$} \\
\hline GWP [kg CO 2 eq.] & 8.70 & 9.64 & $1.10 \times 10^{1}$ & $1.34 \times 10^{1}$ & $1.57 \times 10^{1}$ \\
\hline ODP [kg CFC 11 eq.] & $5.01 \times 10^{-5}$ & $5.01 \times 10^{-5}$ & $5.01 \times 10^{-5}$ & $5.02 \times 10^{-5}$ & $5.02 \times 10^{-5}$ \\
\hline $\mathrm{AP}\left[\mathrm{kg} \mathrm{SO} \mathrm{S}_{2}\right.$ eq. $]$ & $2.57 \times 10^{-2}$ & $2.78 \times 10^{-2}$ & $3.10 \times 10^{-2}$ & $3.63 \times 10^{-2}$ & $4.16 \times 10^{-2}$ \\
\hline $\mathrm{EP}\left[\mathrm{kg}\left(\mathrm{PO}_{4}\right)^{3-}\right.$ eq. $]$ & $4.63 \times 10^{-3}$ & $4.82 \times 10^{-3}$ & $5.11 \times 10^{-3}$ & $5.60 \times 10^{-3}$ & $6.09 \times 10^{-3}$ \\
\hline POCP [kg Ethene eq.] & $2.41 \times 10^{-3}$ & $2.68 \times 10^{-3}$ & $3.07 \times 10^{-3}$ & $3.73 \times 10^{-3}$ & $4.38 \times 10^{-3}$ \\
\hline (ADP-elements) [kg Sb eq.] & $9.90 \times 10^{-3}$ & $9.90 \times 10^{-3}$ & $9.90 \times 10^{-3}$ & $9.90 \times 10^{-3}$ & $9.90 \times 10^{-3}$ \\
\hline (ADP-fossil fuels) [MJ] & $1.55 \times 10^{2}$ & $1.82 \times 10^{2}$ & $2.23 \times 10^{2}$ & $2.90 \times 10^{2}$ & $3.57 \times 10^{2}$ \\
\hline \multicolumn{6}{|c|}{ Environmental aspects related to the consumption of raw materials, $1 \mathrm{~m}^{2}$} \\
\hline PERT [MJ] & 8.70 & 9.09 & 9.69 & $1.07 \times 10^{1}$ & $1.17 \times 10^{1}$ \\
\hline PENRT [MJ] & $1.62 \times 10^{2}$ & $1.90 \times 10^{2}$ & $2.32 \times 10^{2}$ & $3.01 \times 10^{2}$ & $3.70 \times 10^{2}$ \\
\hline
\end{tabular}

Table 3 presents comparable data for ETICS with MW as a thermal insulation material, and the same mineral renders as the final layer.

Table 3. Environmental characteristics of $1 \mathrm{~m}^{2}$ ETICS system described in the National Technical Approval AT-15-2930/2016 calculated in the year 2019 (data from 2017) with 10, 12, 15, 20, and $25 \mathrm{~cm}$ of mineral wool (MW) used as thermal insulation material, and mineral renders as a finishing layer [39].

\begin{tabular}{cccccc}
\hline \multirow{5}{*}{ Indicator [Unit] } & $\mathbf{5} \mathbf{A 1 - A 3}$ \\
\cline { 2 - 6 } & $\mathbf{1 0} \mathbf{~ c m}$ & $\mathbf{1 2} \mathbf{~ c m}$ & $\mathbf{1 5} \mathbf{~ c m}$ & $\mathbf{2 0} \mathbf{~ c m}$ & $\mathbf{2 5} \mathbf{~ c m}$ \\
\hline \multicolumn{5}{c}{ Environmental impacts: $1 \mathrm{~m}^{2}$} \\
\hline GWP [kg CO 2 eq.] & $2.65 \times 10^{1}$ & $3.51 \times 10^{1}$ & $3.72 \times 10^{1}$ & $4.79 \times 10^{1}$ & $5.87 \times 10^{1}$ \\
ODP [kg CFC 11 eq.] & $9.21 \times 10^{-5}$ & $9.25 \times 10^{-5}$ & $9.26 \times 10^{-5}$ & $9.31 \times 10^{-5}$ & $9.35 \times 10^{-5}$ \\
AP [kg SO eq.] $^{3}$ eq. & $1.03 \times 10^{-1}$ & $1.36 \times 10^{-1}$ & $1.45 \times 10^{-1}$ & $1.87 \times 10^{-1}$ & $2.29 \times 10^{-1}$ \\
EP [kg (PO $)^{3-}$ eq.] & $4.22 \times 10^{-3}$ & $5.40 \times 10^{-3}$ & $5.69 \times 10^{-3}$ & $7.16 \times 10^{-3}$ & $8.63 \times 10^{-3}$ \\
POCP [kg Ethene eq.] & $1.28 \times 10^{-2}$ & $1.64 \times 10^{-2}$ & $1.73 \times 10^{-2}$ & $2.19 \times 10^{-2}$ & $2.64 \times 10^{-2}$ \\
(ADP-elements) [kg Sb eq.] & $1.38 \times 10^{-1}$ & $1.89 \times 10^{-1}$ & $2.01 \times 10^{-1}$ & $2.64 \times 10^{-1}$ & $3.27 \times 10^{-1}$ \\
(ADP-fossil fuels) [MJ] & $2.45 \times 10^{2}$ & $3.35 \times 10^{2}$ & $3.58 \times 10^{2}$ & $4.70 \times 10^{2}$ & $5.83 \times 10^{2}$ \\
\hline Environmental aspects related to the consumption of raw materials, $1 \mathrm{~m}^{2}$ \\
\hline PERT [MJ] & 6.26 & 6.26 & 6.26 & 6.26 & 6.26 \\
PENRT [MJ] & $2.69 \times 10^{2}$ & $3.68 \times 10^{2}$ & $3.93 \times 10^{2}$ & $5.17 \times 10^{2}$ & $6.41 \times 10^{2}$ \\
\hline \multicolumn{5}{c}{}
\end{tabular}

Figures 2-10 present mentioned above indicators values calculated for $1 \mathrm{~m}^{2}$ of ETICS with EPS and ETICS with MW, with different thickness of the thermal insulation material. 


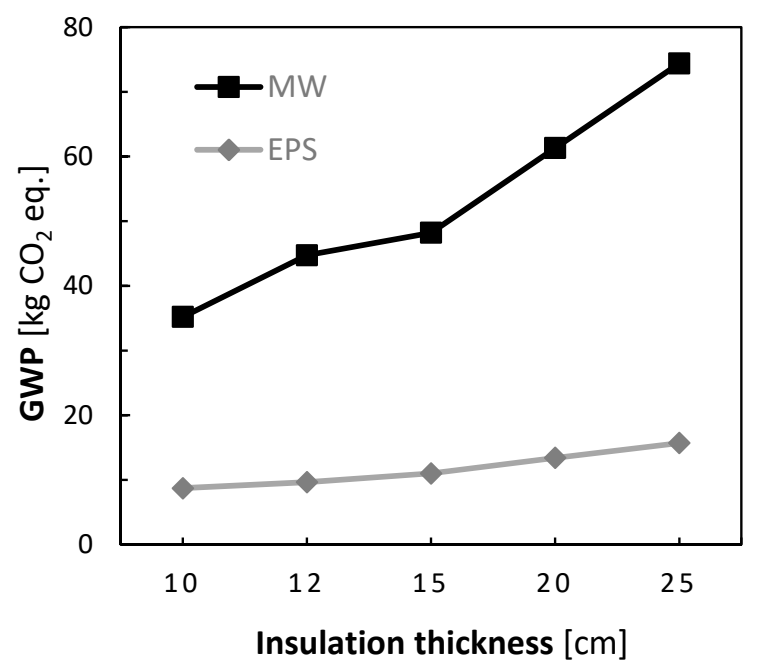

Figure 2. Global warming potential (GWP) for $1 \mathrm{~m}^{2}$ ETICS with EPS or MW depending on the thickness of the thermal insulation material.

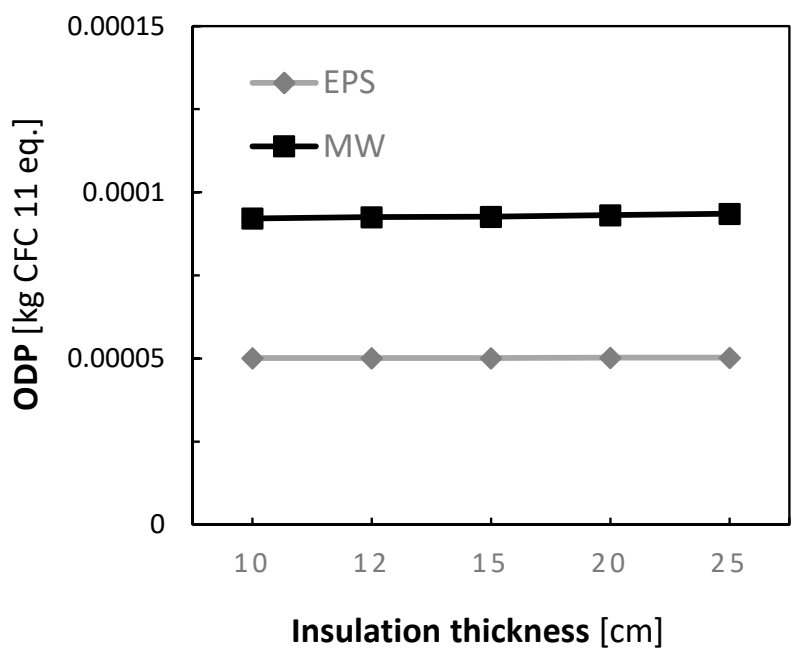

Figure 3. Depletion potential of the stratospheric ozone layer (ODP) for $1 \mathrm{~m}^{2}$ ETICS with EPS or MW depending on the thickness of the thermal insulation material.

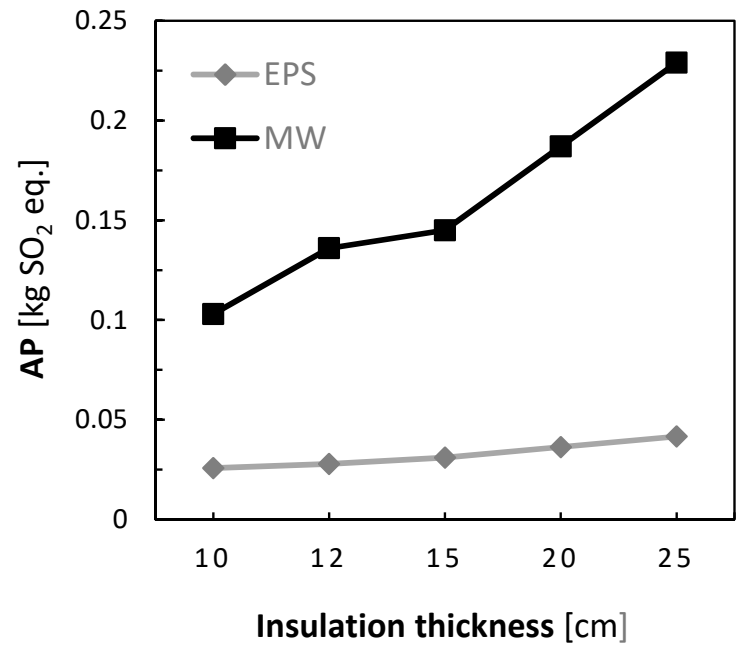

Figure 4. Acidification potential of soil and water (AP) for $1 \mathrm{~m}^{2}$ ETICS with EPS or MW depending on the thickness of the thermal insulation material. 


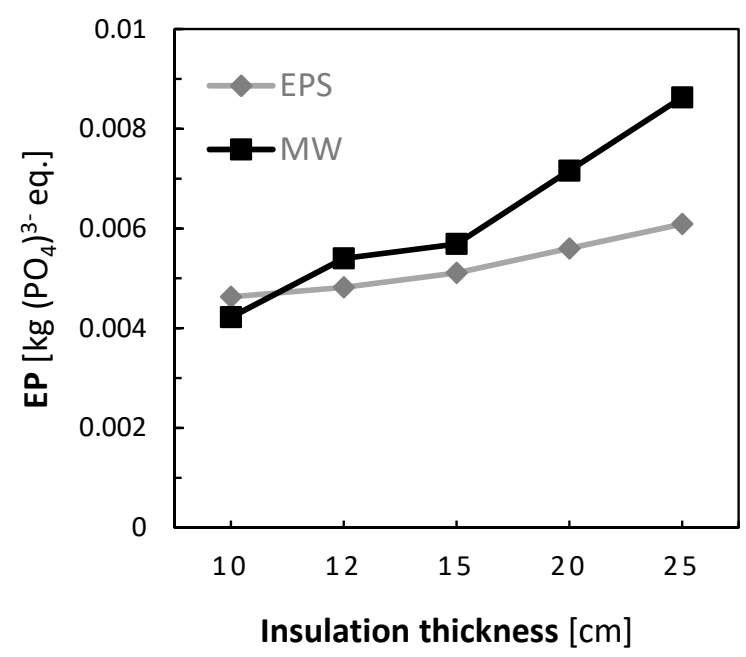

Figure 5. Eutrophication potential (EP) for $1 \mathrm{~m}^{2}$ ETICS with EPS or MW depending on the thickness of the thermal insulation material.

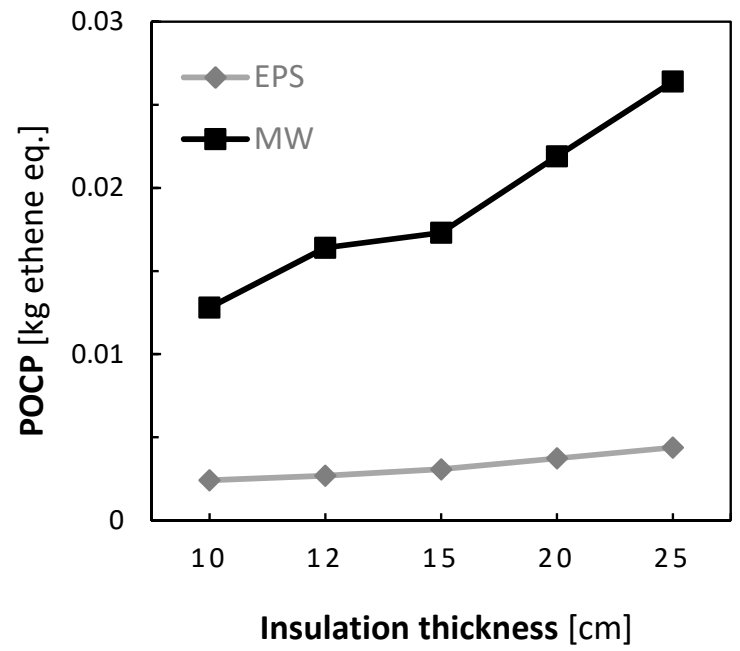

Figure 6. Formation potential of tropospheric ozone (POCP) for $1 \mathrm{~m}^{2}$ ETICS with EPS or MW depending on the thickness of the thermal insulation material.

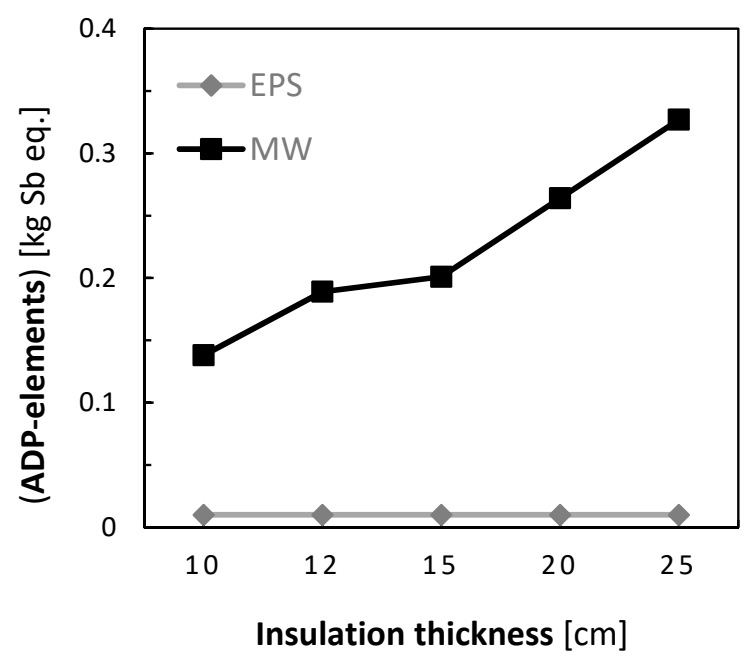

Figure 7. Abiotic depletion potential (ADP-elements) for non-fossil resources for $1 \mathrm{~m}^{2}$ ETICS with EPS or MW depending on the thickness of the thermal insulation material. 


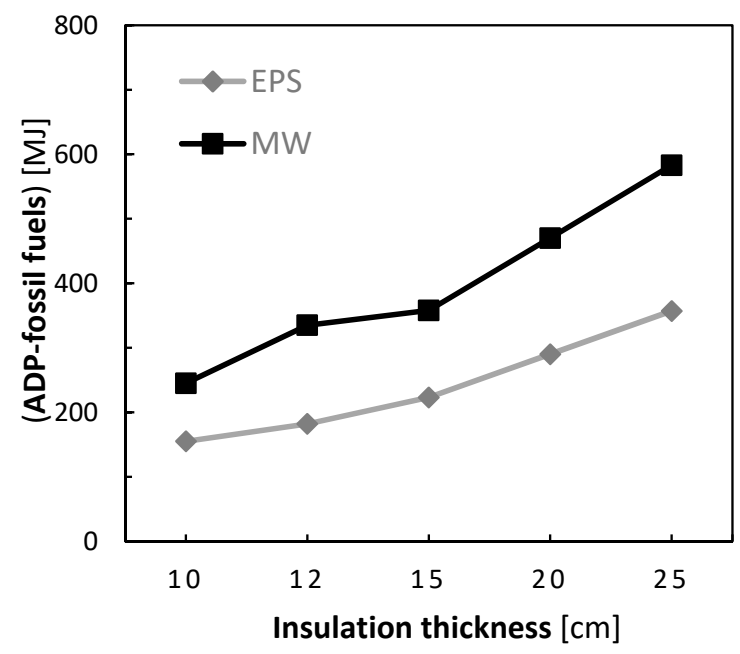

Figure 8. Abiotic depletion potential (ADP-fossil fuels) for total resources for $1 \mathrm{~m}^{2}$ ETICS with EPS or MW depending on the thickness of the thermal insulation material.

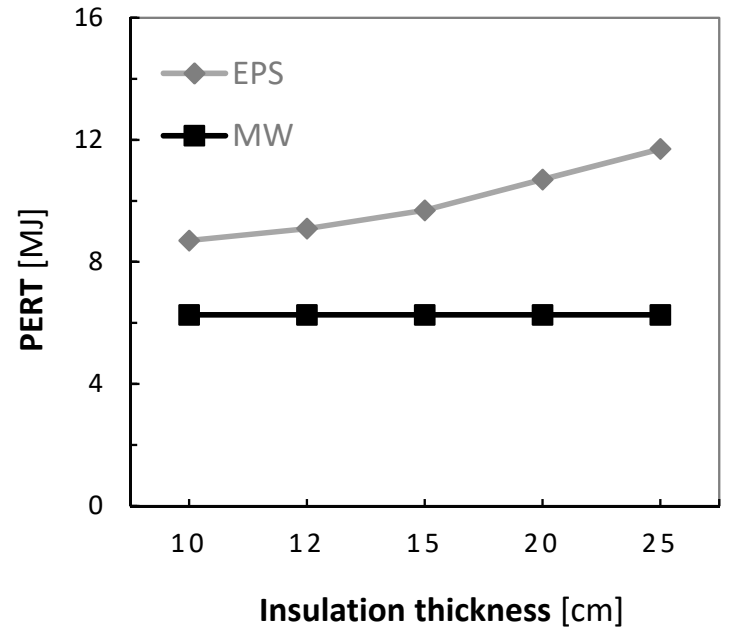

Figure 9. Total use of renewable primary energy resources (primary energy and primary energy resources used as raw materials) (PERT) for $1 \mathrm{~m}^{2}$ ETICS with EPS or MW depending on the thickness of the thermal insulation material.

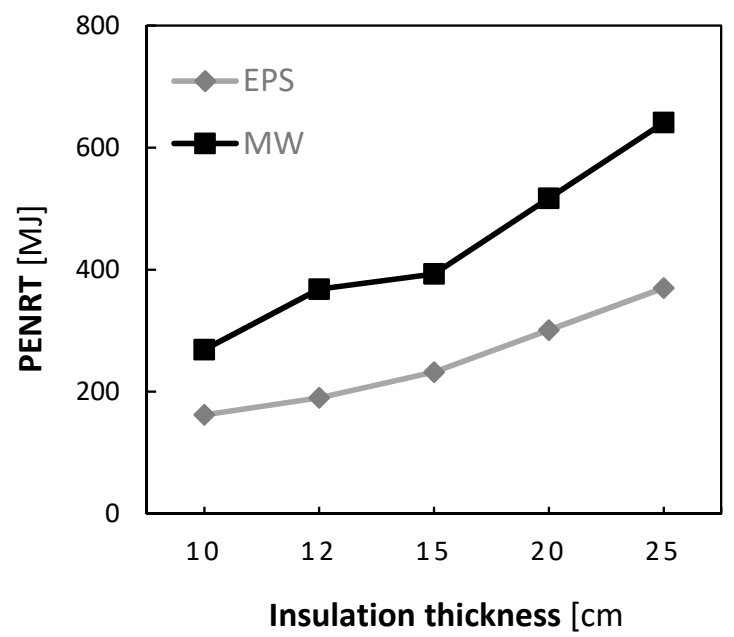

Figure 10. Total use of non-renewable primary energy resources (primary energy and primary energy resources used as raw materials) (PENRT) for $1 \mathrm{~m} 2$ ETICS with EPS or MW depending on the thickness of the thermal insulation material. 
As mentioned earlier, ETICS are kits, in the sense of the CPR, consisting of specified prefabricated components being applied directly to the facade onsite. ETICS are also defined in the same way in the Polish national building regulations. Assessment and verification of constancy of performance of ETICS are carried out for the whole system and not for individual components. For this reason, this work presents a comparison of the environmental impact of $1 \mathrm{~m}^{2}$ ETICS with EPS to $1 \mathrm{~m}^{2}$ ETICS with MW. However, knowledge of the environmental impacts of individual ETICS components is crucial.

Figure 11 shows the share of environmental impacts of individual ETICS components for the system when the thickness of the thermal insulation material is equal to $10 \mathrm{~cm}$.

ETICS with EPS

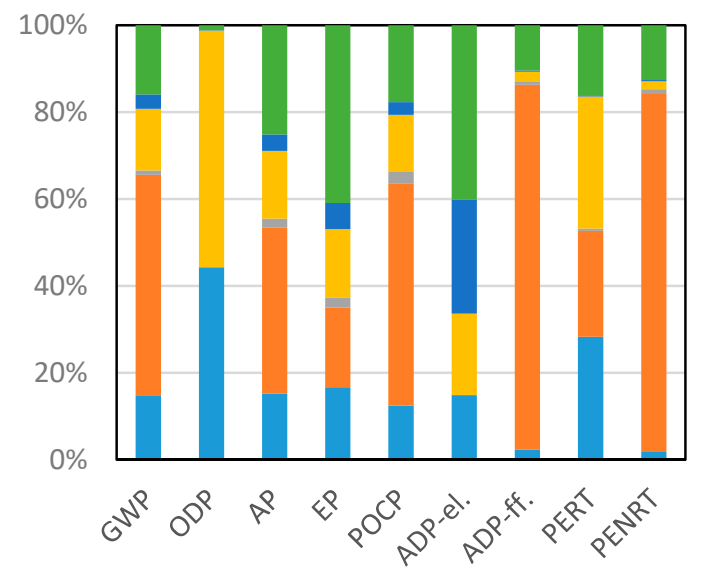

(a)
ETICS with MW

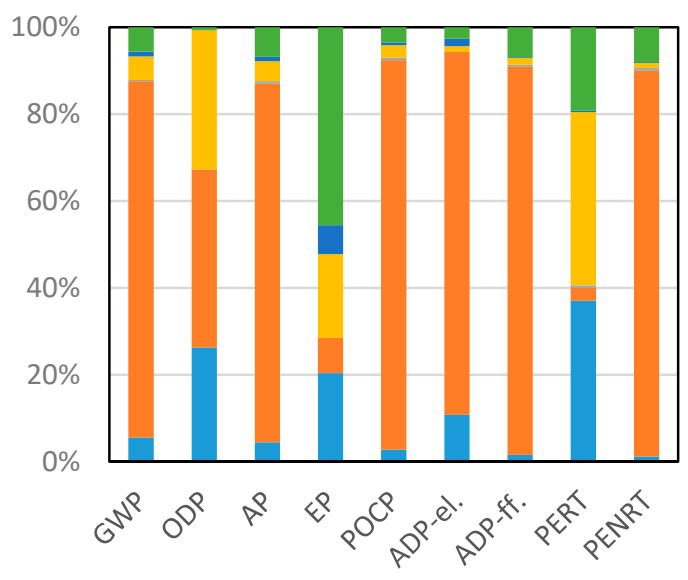

(b)

Figure 11. Environmental impact of complete ETICS system (a) with EPS produced according to the National Technical Approval ITB-15-9090/2016 [36], and (b) with MW produced according to the National Technical Approval ITB-15-2930/2016 [37]. The thickness of the thermal insulation board: $10 \mathrm{~cm}$. The data represent share of specified ETICS system components in the environmental impacts categories (A1-A3 stage of ETICS life-cycle). Legend: ( $\square$ ) adhesive for bonding insulation, ( $\square$ ) insulation material, ( $\square$ ) glass fiber mesh, $(\square)$ adhesive for a base coat, $(\square)$ key coat, ( $\square$ ) finishing coat.

Both thermal insulation materials (EPS and MW) have a significant impact on the value of the studied environmental indicators. EPS footprint was responsible for more than half of GWP, POCP, ADP-fossil fuels, and PENTR. For such indicators as AP, EP, and PERT, contribution of EPS was also significant. The impact of EPS on two environmental indicators (ODP and ADP-elements) was negligible. MW footprint was responsible for almost or more than $90 \%$ of GWP, AP, POCP, ADP-elements, ADP-fossil fuels, and PENRT. MW also has a significant influence on the ODP and relatively small influence for EP and PERT.

\section{Discussion}

For all indicators analyzed in this article, the environmental burdens related to the production of $1 \mathrm{~m}^{2}$ of ETICS with MW were higher than for $1 \mathrm{~m}^{2}$ of ETICS with EPS. Although the value of total use of renewable primary energy resources (PERT) was higher for EPS than for MW, it should be remembered that this is an environmentally beneficial situation.

In the case of the global warming potential (GWP), when comparing the production of $1 \mathrm{~m}^{2}$ ETICS with MW to $1 \mathrm{~m}^{2}$ ETICS with EPS, the first is associated with almost three times higher $\mathrm{CO}_{2}$ equivalent emissions for $10 \mathrm{~cm}$ thick insulation material and nearly four times higher for $25 \mathrm{~cm}$ thick. The Polish ETICS market is one of the largest in the European Union, and its size is estimated at around 40 million $\mathrm{m}^{2}$ of ETICS per year [19]. 
Table 4 presents the global warming potential of manufacturing ETICS (modules A1-A3) calculated for 40 million $\mathrm{m}^{2}$ insulated external walls annually with ETICS with MW (10 and $25 \mathrm{~cm}$ ) and with EPS (10 and $25 \mathrm{~cm}$ ) based on data obtained from data gathered in this paper. When analyzing the above data, it is worth referring to such indicators as the emission of carbon dioxide resulting from heating/cooling activities by households, total $\mathrm{CO}_{2}$ emissions, and total greenhouse gas (GHG) emissions. In 2017 the emission of $\mathrm{CO}_{2}$ resulting from heating/cooling activities by households in Poland was equal to 35.7 million tons [40]. Total $\mathrm{CO}_{2}$ emissions and total GHG emissions in Poland in 2017 were equal to 319.0 million tons of $\mathrm{CO}_{2}$ [41] and 413.8 million tons of $\mathrm{CO}_{2}$ equivalent excluding Land Use, Land Use Change, and Forestry (LULUCF) [42], respectively.

Table 4. Global warming potential of manufacturing ETICS (modules A1-A3) calculated for 40 million $\mathrm{m}^{2}$ insulated external walls annually with ETICS with MW $(10$ and $25 \mathrm{~cm})$ and with EPS $(10$ and $25 \mathrm{~cm})$.

\begin{tabular}{ccc}
\hline \multirow{2}{*}{ Insulation Material Thickness in ETICS $[\mathrm{cm}]$} & \multicolumn{2}{c}{ GWP [t CO $\mathbf{C O}_{\mathbf{2}}$ eq.] } \\
\cline { 2 - 3 } & EPS & MW \\
\hline $10 \mathrm{~cm}$ & 348,000 & $1,060,000$ \\
$25 \mathrm{~cm}$ & 628,000 & $2,348,000$ \\
\hline
\end{tabular}

The stratospheric ozone layer depletion potential (ODP), determining the quantitative impact of the ETICS on the destruction of the ozone layer, is for ETICS with MW nearly two times higher than for the system with EPS. It does not depend on the thickness of the thermal insulation material (EPS or MW). When considering the ozone layer depreciation, ODP, it is worth mentioning that no ozone-depleting substances as regulated by the EU, such as chlorofluorocarbons (CFCs) or hydrochlorofluorocarbons (HCFCs), are nowadays used as blowing agents for the production of EPS [43].

Acidification potential of soil and water (AP) is the result of acids being emitted to the atmosphere and subsequently deposited in surface soils and waters. AP expressed as $\mathrm{SO}_{2}$ equivalent refers to the emission of $\mathrm{SO}_{2}, \mathrm{NO}_{x}, \mathrm{HCl}, \mathrm{NH}_{3}$, and HF. ETICS with MW has a higher AP than ETICS with EPS. The ratio of AP with MW to AP with EPS is varying between 4 and 5.5 for $10 \mathrm{~cm}$ and $25 \mathrm{~cm}$ of thermal insulation material, respectively.

Eutrophication potential (EP) quantitatively determines the impact on the accumulation of organic matter in waters. With the change of MW thickness from 10 to $25 \mathrm{~cm}$, the value of EP increases more than twice (from $4.22 \times 10^{-3}$ to $8.63 \times 10^{-3} \mathrm{~kg}\left(\mathrm{PO}_{4}\right)^{3-}$ eq.). When using EPS, this change with the change in the thickness of the thermal insulation material is not so significant (from $4.63 \times 10^{-3}$ to $6.09 \times 10^{-3} \mathrm{~kg}\left(\mathrm{PO}_{4}\right)^{3-}$ eq. $)$.

The formation potential of tropospheric ozone, POCP, determines the relative abilities of volatile organic compounds to produce ground-level ozone. ETICS with MW is characterized by 5.3 to 6.0 times higher POCP value than ETICS with EPS depending on the thickness of MW/EPS.

The EPS thickness does not affect the value of the abiotic depletion potential (ADP-elements) for non-fossil resources. It is different in the case of ETICS with MW, for which this indicator grows almost three times as the thickness increases from 10 to $25 \mathrm{~cm}$. It is also worth noting that the value of the ADP-elements indicator is $14(10 \mathrm{~cm}$ of thermal insulation material) to $33(25 \mathrm{~cm})$ times higher for ETICS with MW compared to similar systems with EPS.

In the scope of the abiotic depletion potential (ADP-fossil fuels) for fossil resources indicator, ETICS with MW is characterized by higher values.

A comparison of the two PERT and PENRT indicators shows that significantly more non-renewable primary energy resources are used to manufacture ETICS components, regardless of the kind of the thermal insulation material (EPS or MW). For the production of ETICS with EPS, more renewable primary energy and primary energy resources as raw materials were used than for systems with MW. In terms of the PENRT indicator related to the use of non-renewable primary energy resources, ETICS with MW is less environmentally friendly. In the use of renewable and non-renewable primary energy resources (primary energy and primary energy resources used as raw materials), 
significant changes have taken place in Poland in recent years. For the ETICS system with EPS and acrylic renders tested in the scope of modules from A1 to A3, the PERT indicator increased more than seven times while the value of the PENRT indicator decreased by $11 \%$ over five years, from 2012 till 2017 [44].

ETICS improves the energy efficiency of buildings. The energy payback is depending on many factors, like insulation thickness, heating method, and energy source. Also, the original situation, as well as climate, are playing a crucial role. As a rule, the energy payback period of insulating materials is less than two years [45].

\section{Conclusions}

Today, the indoor environment, as well as occupant's health and comfort, are essential topics. It is also crucial to stop the degradation of nature and minimalize the environmental burden due to human activity. Nowadays, we need a holistic approach in which all influencing factors should be simultaneously taken into consideration. Thermal insulation of the external walls plays a key role in saving energy in buildings. It is not only important to know characteristic of ETICS in terms of first six basic requirements according to the CPR; knowledge about the wide-spread sustainability of ETICS is necessary. All decision-makers involved in the construction, as well as in a renovation of buildings, should have access to data related to the environmental influence of building materials, including external thermal insulation composite systems.

From the perspective of several years, the environmental impact may be part of the mandatory assessment and verification of the constancy of the performance of construction materials, including ETICS. The work determines and analyzes the values of nine environmental indicators calculated for ETICS with EPS and MW as a thermal insulation material. Environmental impact rates were calculated for $1 \mathrm{~m}^{2}$ ETICS for five thicknesses of thermal insulation material (EPS or MW). For all nine environmental indicators, mineral wool (MW) systems are characterized by a more negative environmental impact than the equivalent systems with expanded polystyrene (EPS). The value of the PERT indicator for ETICS with EPS is higher than for ETICS with MW. However, the PERT and PENRT indicators should be considered together, comprehensively. Of course, both thermal insulation materials (EPS and MW) are widely used in ETICS, and their technical properties are well known. Both materials, EPS as well as MW, have been in use for decades. However, when deciding to use EPS or MW, it is important to be aware of their different impact on the environment characterized in this work in the scope of modules from A1 to A3.

It should be emphasized that the environmental impact indicators calculated and analyzed in the article refer to the residual data related to significant production (about 10 million $\mathrm{m}^{2}$ ) located in five production plants in different regions of Poland.

The purpose of this work was to show the environmental impact of the production of ETICS with EPS and ETICS with MW (modules A1-A3). ETICS, like other construction products, are not subject to mandatory assessment in terms of the basic requirement for the sustainable use of natural resources. It is essential to publish real industry data. These data, apart from being informative, can help determine evaluation criteria in standardization work. The criteria for assessing building materials, including ETICS, must be realistic. Also, publications in scientific journals are a crucial element of changing awareness in the area of popularizing sustainable development issues.

Author Contributions: Conceptualization: J.M.; formal analysis: M.M., S.C.; investigation: B.M., and J.M.; methodology: B.M., and J.M.; project administration: B.M.; resources: M.M., and S.C.; supervision: J.M., validation: M.M., S.C. and B.M.; visualization, B.M., writing-original draft preparation: J.M., writing-review \& editing: M.M., S.C., B.M., and J.M. All authors have read and agreed to the published version of the manuscript.

Funding: B.M. and M.M. were partially supported by the Regional Operational Programme for Łódzkie Voivodeship 2014-2020 (Project number RPLD.01.02.02-10-014/19-00) and J.M. was partially supported by the Smart Growth Operational Programme 2014-2020 (Project number POIR.02.01.00-00-0350/16).

Acknowledgments: The authors thank Justyna Tomaszewska and Michał Piasecki for their contribution to the development of the ETICS environmental declarations that are the subject of analysis in this work. 
Conflicts of Interest: The authors declare no conflict of interest.

\section{References}

1. European Commission. The European Green Deal; COM (2019) 640 final; European Commission: Brussels, Belgium, 2019.

2. European Economic Area. Annual European Union Greenhouse Gas Inventory 1990-2017 and Inventory Report 2019. Available online: https://www.eea.europa.eu/publications/european-union-greenhouse-gasinventory-201 (accessed on 29 April 2020).

3. European Commission. Commission Welcomes Final Vote on Energy Performance of Buildings, Brussels, Belgium, 2019. Available online: https://ec.europa.eu/commission/presscorner/detail/en/IP_18_3374 (accessed on 29 April 2020).

4. Abergel, T.; Dean, B.; Dulac, J. UN Environment and International Energy Agency (2017): Towards a Zero-Emission, Efficient, and Resilient Buildings and Construction Sector. Global Status Report 2017. Available online: https://www.worldgbc.org/sites/default/files/UNEP\%20188_GABC_en\%20\%28web\%29.pdf (accessed on 29 April 2020).

5. Regulation (EU) No 305/2011 of the European Parliament and of the Council. Available online: https://eur-lex.europa.eu/legal-content/EN/TXT/?uri=uriserv:OJ.L_.2011.088.01.0005.01.ENG\&toc=OJ:L: 2011:088:TOC (accessed on 21 November 2019).

6. The Council of European Communities. Council Directive of 21 December 1988 on the approximation of laws, regulations and administrative provisions of the Member States relating to construction products. Off. J. Eur. Communities 1989, 40, 12-26.

7. Czarnecki, L.; Van Gemert, D. Innovation in construction materials engineering versus sustainable development. Bull. Pol. Acad. Sci. Tech. 2017, 65, 765-771. [CrossRef]

8. Czarnecki, L.; Kapron, M. Sustainable construction as a research area. Int. J. Soc. Mater. Eng. Resour. 2010, 17, 99-106. [CrossRef]

9. Bovea, M.D.; Ibáñez-Forés, V.; Agustí-Juan, I. Environmental product declaration (EPD) labeling of construction and building materials. In Eco-Efficient Construction and Building Materials: Life Cycle Assessment (LCA), Eco-Labelling and Case Studies; Elsevier: Oxford, UK, 2013; pp. 125-150, ISBN 9780857097675.

10. Brinkmann, T.; Metzger, L. Ecological assessment based on environmental product declarations. In Sustainable Production, Life Cycle Engineering and Management, 1st ed.; Springer: Cham, Switzerland, 2019; pp. 21-31.

11. International Organization for Standardization (ISO). ISO 14025:2006 Environmental Labels and Declarations-Type III Environmental Declarations_Principles and Procedures; International Organization for Standardization (ISO): Geneva, Switzerland, 2006.

12. European Committee for Standardization (CEN). EN 15978:2011 Sustainability of Construction Works-Assessment of Environmental Performance of Buildings-Calculation Method; European Committee for Standardization (CEN): Brussels, Belgium, 2011.

13. European Committee for Standardization (CEN). EN 15804:2012+A2:2019 Sustainability of Construction Works-Environmental Product Declarations-Core Rules for the Product Category of Construction Products; European Committee for Standardization (CEN): Brussels, Belgium, 2019.

14. Anderson, J. Construction LCA's 2020 Guide to Environmental Product Declarations. Available online: infogram.com/constructionlcas-2020-guide-to-epd-1h7g6kgqx9zo4oy?live (accessed on 30 November 2019).

15. Building Research Institute (ITB). General Information about Research Building Institute EPD Program. Available online: https://www.itb.pl/epd.html (accessed on 16 January 2020).

16. Bitsiou, E.; Giarma, C. Parameters related to building components' life-cycle analysis in methods for buildings' environmental performance assessment. IOP Conf. Ser. Earth Environ. Sci. 2020, 410, 012066. [CrossRef]

17. Andersen, S.C.; Larsen, H.F.; Raffnsøe, L.; Melvang, C. Environmental Product Declarations (EPDs) as a competitive parameter within sustainable buildings and building materials. IOP Conf. Ser. Earth Environ. Sci. 2019, 323, 012145. [CrossRef]

18. Gelowitz, M.D.C.; McArthur, J.J. Investigating the Effect of Environmental Product Declaration Adoption in LEED $^{\circledR}$ on the Construction Industry: A Case Study. Procedia Eng. 2016, 145, 58-65. [CrossRef] 
19. Pasker, R. The European ETICS market-Do ETICS sufficiently contribute to meet political objectives? In Proceedings of the 4th European ETICS Forum; Warsaw, Poland, 5 October 2017; European Association for External Thermal Insulation Composite Systems (EAE): Baden-Baden, Germany, 2017.

20. Balaras, C.A.; Droutsa, K.; Dascalaki, E.; Kontoyiannidis, S. Heating energy consumption and resulting environmental impact of European apartment buildings. Energy Build. 2005, 37, 429-442. [CrossRef]

21. Papadopoulos, A.M. State of the art in thermal insulation materials and aims for future developments. Energy Build. 2005, 37, 77-86. [CrossRef]

22. Wieland, H.; Murphy, D.P.; Behring, H.; Jäger, C.; Hinrichs, P.; Bockisch, F.-J. Perspektiven für Dämmstoffe aus heimischen nachwachsenden Rohstoffen. Landtech Eng. 2000, 55, 22-23.

23. Aditya, L.; Mahlia, T.M.I.; Rismanchi, B.; Ng, H.M.; Hasan, M.H.; Metselaar, H.S.C.; Muraza, O.; Aditiya, H.B. A review on insulation materials for energy conservation in buildings. Renew. Sustain. Energy Rev. 2017, 73, 1352-1365. [CrossRef]

24. Karamanos, A.; Hadiarakou, S.; Papadopoulos, A.M. The impact of temperature and moisture on the thermal performance of stone wool. Energy Build. 2008, 40, 1402-1411. [CrossRef]

25. European Committee for Standardization (CEN). EN 13501-1:2018. Fire Classification of Construction Products and Building Elements-Part 1: Classification Using Data from Reaction to Rire Tests; European Committee for Standardization (CEN): Brussels, Belgium, 2018.

26. The Polish Committee for Standardization (PKN). PN-B-02867:2013. Ochrona Przeciwpożarowa Budynków. Metoda Badania Stopnia Rozprzestrzeniania Ognia Przez Ściany Zewnętrzne od Strony Zewnętrznej Oraz Zasady Klasyfikacji; Polski Komitet Normalizacyjny (PKN): Warsaw, Poland, 2013.

27. Silvestre, J.D.; Castelo, A.M.P.; Silva, J.J.B.C.; Brito, J.M.C.L.; Pinheiro, M.D. Retrofitting a building's envelope: Sustainability performance of ETICS with ICB or EPS. Appl. Sci. 2019, 9, 1285. [CrossRef]

28. Sattler, S.; Österreicher, D. Assessment of sustainable construction measures in building refurbishment-life cycle comparison of conventional and Multi-Active Façade systems in a social housing complex. Sustainability 2019, 11, 4487. [CrossRef]

29. Sierra-Pérez, J.; Boschmonart-Rives, J.; Gabarrell, X. Environmental assessment of façade-building systems and thermal insulation materials for different climatic conditions. J. Clean. Prod. 2016, 113, 102-113. [CrossRef]

30. Bisegna, F.; Mattoni, B.; Gori, P.; Asdrubali, F.; Guattari, C.; Evangelisti, L.; Sambuco, S.; Bianchi, F. Influence of insulating materials on green building rating system results. Energies 2016, 9, 712. [CrossRef]

31. Dylewski, R.; Adamczyk, J. Study on ecological cost-effectiveness for the thermal insulation of building external vertical walls in Poland. J. Clean. Prod. 2016, 133, 467-478. [CrossRef]

32. Michałowski, B.; Marcinek, M.; Tomaszewska, J.; Czernik, S.; Piasecki, M.; Geryło, R.; Michalak, J. Influence of rendering type on the environmental characteristics of expanded polystyrene-based external thermal insulation composite system. Buildings 2020, 10, 47. [CrossRef]

33. European Organization for Technical Assessment (EOTA). ETAG 004: Guideline for European Technical Approval of External Thermal Insulation Composite Systems (ETICS) with Rendering; European Organization for Technical Assessment (EOTA): Brussels, Belgium, 2013.

34. Building Research Institute (ITB); Institute of Ceramics and Building Materials (ICiMB); Institute of Mechanized Construction and Rock Mining (IMBiGS). Warunki Oceny Właściwości Użytkowych Wyrobu Budowlanego WO-KOT/04/02-Złożone Zestawy Izolacji Cieplnej z Wyprawami Tynkarskimi (ETICS) z Zastosowaniem Wyrobów ze Styropianu, 1st ed.; Building Research Institute (ITB): Warsaw, Poland, 2018.

35. Building Research Institute (ITB); Institute of Ceramics and Building Materials (ICiMB); Institute of Mechanized Construction and Rock Mining (IMBiGS). Warunki Oceny Właściwości Użytkowych Wyrobu budowlAnego WO-KOT/04/01-Złożone Zestawy Izolacji Cieplnej z Wyprawami Tynkarskimi (ETICS) z Zastosowaniem Wyrobów Z Wetny Mineralnej, 1st ed.; Building Research Institute (ITB): Warsaw, Poland, 2018.

36. Building Research Institute (ITB). National Technical Approval ITB-AT-9090/2016 Zestaw Wyrobów do Wykonywania Ociepleń ścian Zewnętrznych Budynków Systemem Atlas ETICS; Building Research Institute (ITB): Warsaw, Poland, 2016.

37. Building Research Institute (ITB). National Technical Approval ITB-AT15-2930/2016 Zestaw Wyrobów do Wykonywania Ociepleń Ścian Zewnętrznych Budynków Systemem Atlas ROKER; Building Research Institute (ITB): Warsaw, Poland, 2016. 
38. Atlas. Environmental Product Declaration, Atlas ETICS External Thermal Insulation Composite System with Expanded Polystyrene Boards (EPS), Certificate No 078/2019; Atlas: Warsaw, Poland, 2019.

39. Atlas. Environmental Product Declaration, Atlas ETICS External Thermal Insulation Composite System with Mineral Wool Boards (MW), Certificate No 078/2019; Atlas: Warsaw, Poland, 2019.

40. Eurostat. The statistical office of the European Union. NACE Rev. 2 Statistical Classification of Economic Activities in the European Community; Publications Office of the European Union: Luxembourg, 2020.

41. Muntean, M.; Guizzardi, D.; Schaaf, E.; Crippa, M.; Solazzo, E.; Olivier, J.G.J.; Vignati, E. Fossil CO 2 Emissions of all World Countries-2018 Report; Publications Office of the European Union: Luxembourg, 2018.

42. European Environment Agency (EEA). The European Environment-State and Outlook 2020. Knowledge for the Transition to a Sustainable Europe; Publications Office of the European Union: Luxembourg, 2019; ISBN 9789294800909.

43. EUMEPS. Environmental Product Declaration Expanded Polystyrene (EPS) Foam Insulation; Institut Bauen und Umwelt e.V. (IBU): Berlin, Germany, 2017.

44. Michałowski, B.; Marcinek, M.; Tomaszewska, J.; Czernik, S.; Piasecki, M.; Geryło, R.; Michalak, J. Charakterystyka środowiskowa systemów ETICS w latach 2014-2019 (Environmental characteristics of the ETICS systems between 2014 and 2019). Mater. Bud. 2019, 12, 22-25.

45. Kienzlen, V.; Erhorn, H.; Krapmeier, H.; Lutzkendorf, T.; Werner, J.; Wagner, A. The Significance of Thermal Insulation Arguments Aimed at Overcoming Misunderstandings, 3rd ed.; Fraunhofer-Publica: Karlsruhe, Germany, 2014; p. 35.

(C) 2020 by the authors. Licensee MDPI, Basel, Switzerland. This article is an open access article distributed under the terms and conditions of the Creative Commons Attribution (CC BY) license (http://creativecommons.org/licenses/by/4.0/). 